\title{
Sodium Regulation of Angiotensinogen mRNA Expression in Rat Kidney Cortex and Medulla
}

Julie R. Ingelfinger, "¥ Richard E. Pratt," Kristin Ellison," and Victor J. Dzau*

*Molecular and Cellular Vascular Research Laboratory, Division of Vascular Medicine and Atherosclerosis, Brigham and Women's Hospital, and ¥Division of Nephrology, The Children’s Hospital, Harvard Medical School, Boston, Massachusetts 02115

\begin{abstract}
Rat liver angiotensinogen cDNA (pRang 3) and mouse renin cDNA (pDD-1D2) were used to identify angiotensinogen and renin mRNA sequences in rat kidney cortex and medulla in rats on high and low salt diet. Angiotensinogen mRNA sequences were present in renal cortex and medulla in apparently equal proportions, whereas renin mRNA sequences were found primarily in renal cortex. Average relative signal of rat liver to whole kidney angiotensinogen mRNA was 100:3. Densitometric analysis of Northern blots demonstrated that renal cortical angiotensinogen mRNA concentrations increased 3.5-fold ( $P$ $<0.001)$ and medulla, 1.5 -fold $(P<0.005)$ on low sodium compared with high sodium diet, whereas renal cortex renin mRNA levels increased 6.8-fold $(P<0.0005)$. Dietary sodium did not significantly influence liver angiotensinogen mRNA levels. These findings provide evidence for sodium regulation of renal renin and angiotensinogen mRNA expressions, which supports potential existence of an intrarenally regulated RAS and suggest that different factors regulate renal and hepatic angiotensinogen.
\end{abstract}

\section{Introduction}

An enlarging body of data suggests that multiple components of the renin-angiotensin system may be found locally in a number of tissues. The presence of renin, angiotensin I (AI) ${ }^{1}$, and AII has been detected biochemically in intact kidney as well as in cultured kidney cells $(1,2)$. Whether or not angiotensinogen is produced in the kidney has been a matter of some debate. While some investigators, using biochemical assays, have reported the presence of angiotensinogen within the kidney, others have not (3-7). Furthermore, the sites in which angiotensinogen has been detected have also varied $(3,6,7)$.

Since the first report by Page that angiotensinogen was released by liver (8), it has generally been accepted that the circulation-bourne substrate is rate limiting in the production of angiotensins. However, angiotensinogen expression has been recently demonstrated in the brain (9-12). This raises the question as to whether local angiotensin production is more dependent on tissue angiotensinogen concentration. If angiotensinogen is present in the kidney, it would provide a means of local and rapid production of angiotensin. Because the renin-angiotensin

Address correspondence and reprint requests to Dr. Ingelfinger or Dr. Dzau, Brigham and Women's Hospital, 75 Francis Street, Boston, MA 02115.

Received for publication 17 June 1986.

1. Abbreviation used in this paper: $\mathrm{AI}$, angiotensin $\mathrm{I}$.

J. Clin. Invest.

(c) The American Society for Clinical Investigation, Inc. 0021-9738/86/11/1311/05 \$1.00

Volume 78, November 1986, 1311-1315 system is intimately involved in renal autoregulation, an intrarenal source of angiotensinogen could potentially facilitate alterations in the activity of the system in local areas independent of the circulating renin-angiotensin levels.

In the present investigation we used a full length CDNA probe to mouse renin and a 530-base cDNA probe to rat liver angiotensinogen to identify mRNA sequences encoding these polypeptides in whole rat kidney. We studied the regional distribution of renin and angiotensinogen mRNAs in the kidney and examined regional responses to sodium intake. Our results indicated that the rat kidney contains angiotensinogen mRNA sequences in both the cortex and medulla, and that low sodium diet stimulated renal angiotensinogen and renin gene expressions as compared with high-sodium diet, but did not influence hepatic angiotensinogen mRNA level.

\section{Methods}

Animals. Wistar-Kyoto rats aged 16 wk were obtained from the Charles River Breeding Laboratories, Inc. (Wilmington, MA) and housed in our animal care facility until time of investigation. A total of 28 rats were put on high salt $(n=14)$ and low salt diets $(n=14)$ (see below).

Diet. At baseline, animals were fed standard lab chow (Ralston Purina Co., St. Louis, MO). For low/high salt studies they were fed chow (Teklad Test Diets, Madison, WI), containing 0.02 or $3 \% \mathrm{NaCl}$ (wt/wt) for 2 wk. In low salt animals, furosemide, $1 \mathrm{mg}$ was administered subcutaneously on days $1-3$ to induce salt depletion. To verify dietary condition, urinary sodium concentration $\left(\mathrm{U}_{\mathrm{Na}+}\right)$ was determined on bladder urine at the time of sacrifice.

Plasma renin concentration. In rats on high and low salt diets, plasma was collected at the time of sacrifice in chilled EDTA tubes. Plasma renin concentration was assayed by $\mathrm{AI}$ generation on incubation with renin-free plasma from nephrectomized dogs at $37^{\circ} \mathrm{C}(\mathrm{pH} 7.4)$ as described (13).

Tissue handling. Rats were killed by rapid decapitation using a guillotine. Organs were snap-frozen in liquid nitrogen for subsequent study. Renal tissue was either frozen whole, or was dissected within $3 \mathrm{~min}$. Outer cortex and inner medullary stripe were separated for further study. Because the outer medullary stripe may contain cortex, this portion was not studied.

Isolation of total RNA. Renal tissue was stored at $-70^{\circ} \mathrm{C}$ until homogenized in $4 \mathrm{M}$ guanidine thiocyanate, $0.5 \% \mathrm{Na}-\mathrm{N}$-lauryl sarcosine, $25 \mathrm{mM} \mathrm{Na}$ citrate, and $0.1 \mathrm{M}$ beta-mercaptoethanol $(14,15)$. Homogenate (1 $\mathrm{gm}$ tissue/10 ml beta-mercaptoethanol) was applied to $5 \mathrm{ml}$ of autoclaved 5.7 $\mathrm{M} \mathrm{CsCl}_{2}$ and $25 \mathrm{mM} \mathrm{Na}$ Acetate ( $\mathrm{pH}$ 5.5). Preparations were subjected to ultracentrifugation in a Ti 70.1 rotor (Beckman Instruments Inc., Fullerton, CA) for $16 \mathrm{~h}$ at $20^{\circ} \mathrm{C}$ at $35,000 \mathrm{rpm}$ (relative centrifugal force $=8.4 \times 10^{4} \mathrm{~g}$ ), and total RNA resuspended in $0.2 \mathrm{M} \mathrm{Na}$ Acetate (pH 5.5), rocked in the cold for $1 \mathrm{~h}$, and then ethanol-precipitated. Total RNA, collected by centrifugation and dissolved in sterile $\mathrm{H}_{2} \mathrm{O}$, was quantitated by absorbance readings at $260 \mathrm{~nm}(1 \mathrm{U}=40 \mu \mathrm{g}$ RNA). Desired amount of RNA was aliquoted for future use and stored at $-70^{\circ} \mathrm{C}$.

Gel electrophoresis and hybridization studies. RNA was lyophilized, denatured with glyoxal, and applied to $1.5 \%$ agarose gels. Denaturing mixture consisted of $1.2 \mathrm{M}$ glyoxal, $50 \% \mathrm{vol} / \mathrm{vol}$ dimethyl sulfoxide, and $0.01 \mathrm{M} \mathrm{NaH}_{2} \mathrm{PO}_{4}$ (pH 7.0) (16); $24 \mu \mathrm{l}$ was used for $\leq 100 \mu \mathrm{g} \mathrm{RNA}$, and 
1.5 times the volume for larger amounts. Gels ran at $100 \mathrm{~mA}$ for $4 \mathrm{~h}$ in $0.01 \mathrm{M} \mathrm{NaPO}_{4}$ buffer with constant recirculation. A mixture of Hae IIIdigested $₫ \mathrm{X} 174$ and Hind III-digested lambda was run to provide size markers. For simplicity, only the $2.0-\mathrm{kb}$ fragment from lambda and the $1.3-\mathrm{kb}$ fragment from $\otimes \mathrm{X} 174$ is included in the figure.

Gels were transblotted by capillary action with 10× SSC (standard sodium citrate) for $20 \mathrm{~h}$ onto nylon filters (Gene Screen, New England Nuclear, Boston, MA) (17). Filters were then baked at $80^{\circ} \mathrm{C}$ in a vacuum oven for $2 \mathrm{~h}$, prehybridized at $42^{\circ} \mathrm{C}$ for $3-4 \mathrm{~h}$ in a buffer consisting of $5 \times$ SSC, $50 \%$ formamide, $5 \times$ Denhardt's solution, $25 \mu \mathrm{g} / \mathrm{ml}$ yeast tRNA, and $25 \mu \mathrm{g} / \mathrm{ml}$ salmon sperm DNA in $0.2 \%$ SDS. The blots were hybridized overnight in the same buffer and temperature to which was added to nick-translated ${ }^{32} \mathrm{P}$-labeled renin cDNA pDD-1D2 (a full length probe to mouse renin) (18) or ${ }^{32} \mathrm{P}$-labeled angiotensinogen cDNA pRang 3 (partial length rat angiotensinogen cDNA) (10) at $2 \times 10^{6} \mathrm{cpm} / 5 \mathrm{ml}$ buffer. After post-hybridization washing in $0.5 \times$ SSC and $0.1 \%$ SDS at $56^{\circ} \mathrm{C}$, blots were dried and autoradiographed.

After a filter had been used for hybridization study with one of the probes, it was re-used. The first cDNA probe was removed from the filter-bound RNA by boiling in $\mathrm{H}_{2} \mathrm{O}$ for $5 \mathrm{~min}$ and the filter exposed overnight to ensure that no residual radioactivity remained. The washed filter could then be used for hybridization with the second probe. Thus, co-expression of renin and angiotensinogen mRNAs in a given tissue could be determined. As control, total RNA from CD-1 male mouse submandibular gland (SMG), which contained high levels of renin mRNA, was used for hybridization with pDD-1D2. Similarly, rat liver total RNAs were run as controls in hybridization studies with angiotensinogen probe pRang 3.

Quantification of $m R N A$. Serial quantities of total RNA from each organ were used for hybridization, and autoradiographs were scanned with an LKB microdensitometer (Paramus, NJ); the background was set to zero for each autoradiograph scanned. External ${ }^{35} \mathrm{~S}$ standards were placed on film along with the blot to be sure film responded linearly. Regression lines were calculated from integral values thereby generated, and relative signals of the specific mRNA were estimated from the slope of the regression line. When the linearity for each series of dilutions was analyzed, only $r$ values $\geq 0.90$ were accepted; transfer of 25,50 , and 100 $\mu \mathrm{g}$ was thus linear. Slopes of specific mRNAs from low and high salt studies were compared. Student's $t$ tests were performed on the logarithms of the ratios of slopes (low salt/high salt) observed, as compared with the logarithm of an expected ratio of equality $(\log 1=0)$. Comparison of mRNA levels of each tissue in response to sodium diet was only made using densitometric analysis within a single autoradiogram, thus eliminating the need for an external RNA standard. If multiple exposures were necessary, the data were corrected for exposure time and, if necessary, radioisotopic decay. Six separate Northern blots were performed on three RNA preparations from pooled kidney cortex and medulla. Each preparation represented four to five kidneys pooled from different animals.

Renin and angiotensinogen cDNA. We used the angiotensinogen probe pRang 3, cloned by Lunch et al. (10) into the BAM H1 site of pUC9. This partial length rat liver cDNA corresponds to nucleotides 650-1140 of rat angiotensinogen CDNA sequence, as published of Okhubo and colleagues (19). The renin cDNA pDD-1D2 is a full length mouse submaxillary gland renin cDNA cloned by Field et al. (18) into the Pst 1 site of pBR 322. It hybridizes readily to rat renin mRNA (9).

Labeling of $c D N A$. cDNA inserts for renin (pDD-1D2) or angiotensinogen (pRang 3) $(0.8 \mu \mathrm{g})$ were labeled by nick-translation with $150 \mu \mathrm{Ci}$ $\left(\alpha^{32} \mathrm{P}\right)$ dCTP $(1000-1500 \mathrm{Ci} / \mathrm{mmol})$ (New England Nuclear) as described (17). Sephadex G-100 gel filtration chromatography was used to purify the labeled cDNA. The specific activity of each probe was $\sim 1-2 \times 10^{8}$ $\mathrm{cpm} / \mu \mathrm{g}$ DNA.

\section{Results}

Plasma renin activity and urinary electrolytes. Plasma renin activity performed in rats on high and low salt diets was 4.0 \pm 1.1 ng Al/h per $\mathrm{ml}$ and $13.8 \pm 1.8 \mathrm{ng} \mathrm{AI} / \mathrm{h}$ per $\mathrm{ml},(P<0.05)(n=6$
Table 1. Plasma Renin Concentrations and Urine Sodium Concentrations in Wistar-Kyoto Rats on High and Low Salt Diets

\begin{tabular}{llll}
\hline & Low sodium diet & High sodium diet & $P$ \\
\hline $\begin{array}{l}\text { Plasma renin } \\
\text { concentration } \\
\text { (ng AI/ml per } \mathrm{h})\end{array}$ & $13.8 \pm 1.8$ & $4.0 \pm 1.1$ & $<0.05$ \\
$\begin{array}{l}\text { Urinary sodium } \\
\text { concentration } \\
\text { (mEq/liter) }\end{array}$ & $2.7 \pm 1.5$ & $103 \pm 25$ & $<0.005$ \\
\hline
\end{tabular}

$n=6$.

for each) respectively. Table I shows urinary sodium concentrations of rats while they were on low and high salt diets. Urinary sodium concentrations of $103 \pm 25$ and $2.7 \pm 1.5 \mathrm{meq} / \mathrm{liter}(P$ $<0.005)$ ( $n=6$ rats for each) were measured for rats on high and low salt diets, respectively. Individual urine and plasma were not available in the other eight rats in either condition. However, pooled samples from these rats gave similar plasma renin values and urinary sodium values on the individual animals (data not shown).

Northern blot hybridization analysis. Nick-translated cDNA probes for both angiotensinogen and renin hybridized to total RNA from whole kidney. All experiments were reproduced six times on separate Northern blots. Angiotensinogen mRNA in rat kidney was generally comparable in size to the rat liver counterpart ( 1800 bases as calculated from nucleotide sequence). We have observed that the angiotensinogen mRNA band is broad in some blots. This was previously noted by Ohkubo et al. (20), who suggested that this observation may reflect heterogeneity of the mRNA. The average relative signal for angiotensinogen mRNA in rat liver and kidney was 100:3. Both rat renal cortex and medulla contained RNA sequences that hybridized to the nick-translated angiotensinogen probe, pRang 3 . In rats on normal diet, angiotensinogen mRNA existed in comparable levels in renal cortex and medulla (Fig. 1). Rat renal renin mRNA migrated on agarose gel electrophoresis with an apparent size of

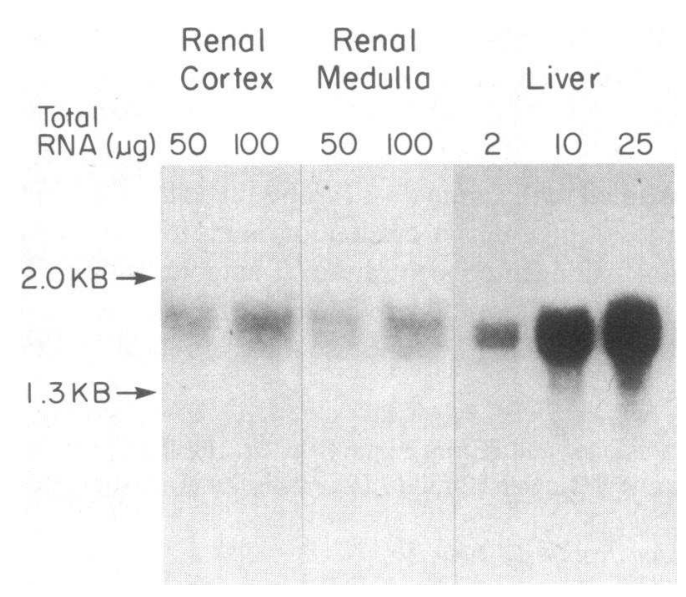

Figure 1. Representative Northern blot analysis of serial quantities of total RNA from renal cortex, medulla, and liver of rats on normal diet, hybridized to nick-translated $\alpha^{32}$ P-labeled angiotensinogen cDNA (pRang3). (Specific activity was $2 \times 10^{8} \mathrm{cpm} / \mu \mathrm{g}$ DNA.) Autoradiogram was exposed $144 \mathrm{~h}$. 
1550 bases. This is in agreement with the size of mouse renin mRNA as calculated from nucleotide sequence of the full length cDNA. Using nick-translated renin CDNA, positive hybridization was readily detected with cortical RNA. On long exposure of blots containing medullary RNA hybridized to $1 \mathrm{D} 2$, sequences for renin mRNA could be detected and appeared to be $\sim 5 \%$ of cortical levels.

Based on signals generated on Northern blot analysis, renal cortical angiotensinogen mRNA was estimated to be 3.5-fold higher in animals maintained on a low salt diet as compared with high salt diet $(P<0.001)$, while cortical renin mRNA level was approximately seven times higher $(P<0.0005)$. Similarly, renal medullary angiotensinogen mRNA level was 1.5 times greater on low salt as compared with high salt diet $(P<0.005)$
(Figs. 2 and 3). The level of medullary renin mRNA concentration was too low for an accurate evaluation of its response to low sodium. Hepatic angiotensinogen mRNA concentration did not change with sodium intake (Figs. 2 and 3). All analyses were performed on blots that were first hybridized to angiotensinogen and then subsequently to renin cDNA probes.

\section{Discussion}

The concept of an intrarenal renin-angiotensin system for regulation of local hemodynamics is attractive. However, direct, definitive evidence for local angiotensin production in the kidney has been difficult to obtain. Biochemical detection of components
A.

\section{ANGIOTENSINOGEN MRNA}
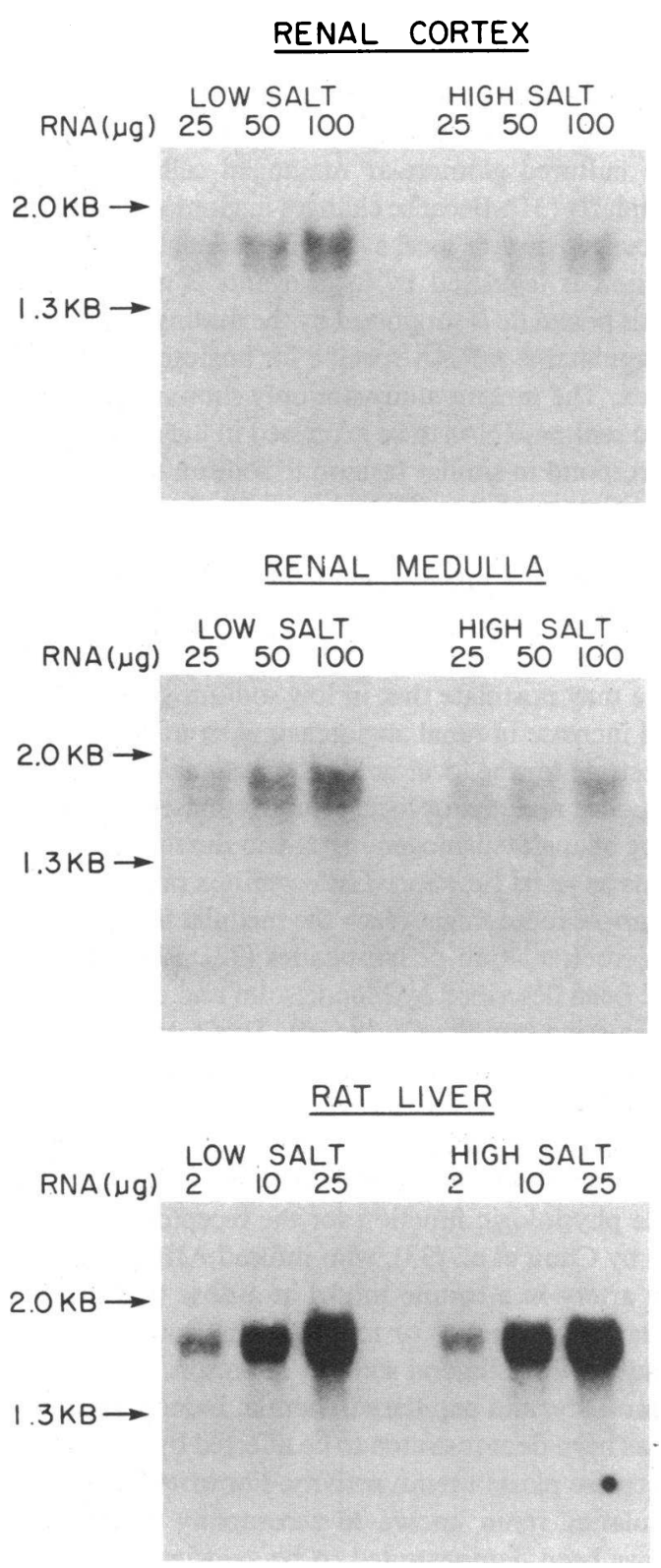

B.
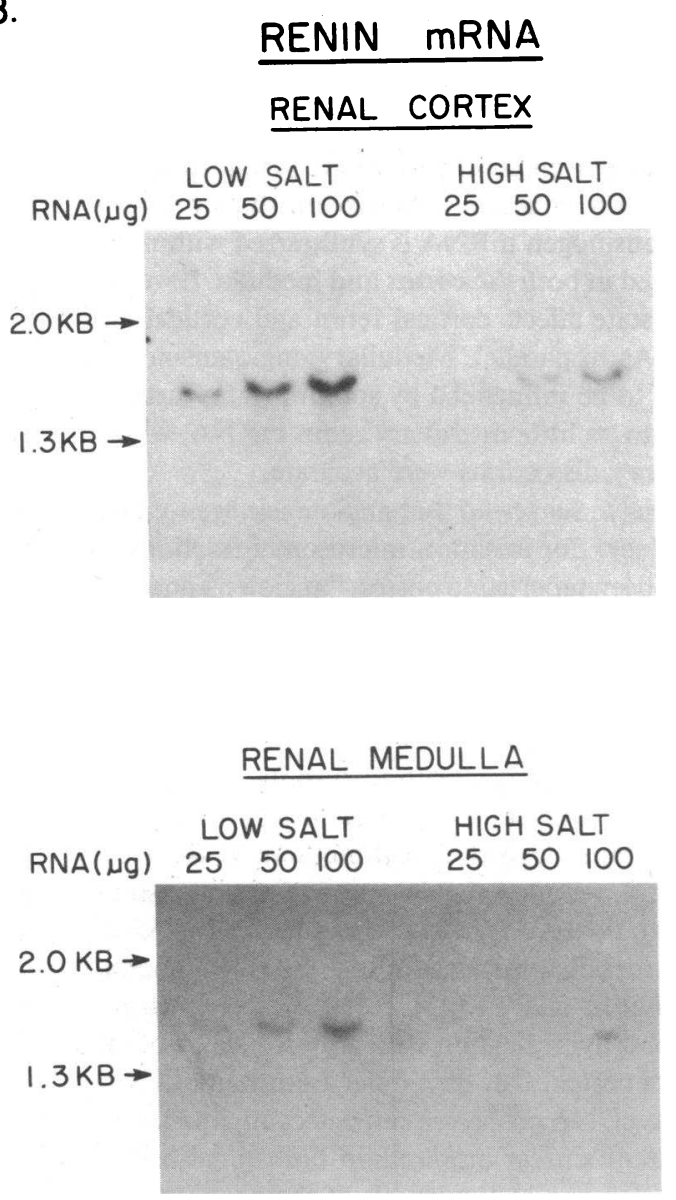

Figure 2. (A) Representative Northern blot analysis of serial quantities of total RNA from renal cortex, medulla, and liver of rats on low and high sodium diets, hybridized to nick-translated $\alpha^{32}$ P-labeled angiotensinogen cDNA (pRang 3). (Specific activity was $2 \times 10^{8} \mathrm{cpm} / \mu \mathrm{g}$ DNA.) The autoradiogram was exposed for $144 \mathrm{~h}$. (B) Representative Northern blot analysis of serial quantities of total RNA from renal cortex and medulla of rat on low and high sodium diets, hybridized to nick-translated $\alpha^{32} \mathrm{P}$-labeled renin cDNA (pDD-1D2). (Specific activity was $2 \times 10^{8} \mathrm{cpm} / \mu \mathrm{g}$ DNA.) The autoradiogram of cortical RNA was exposed for $48 \mathrm{~h}$, whereas the autoradiogram of medullary RNA was exposed for $144 \mathrm{~h}$. 


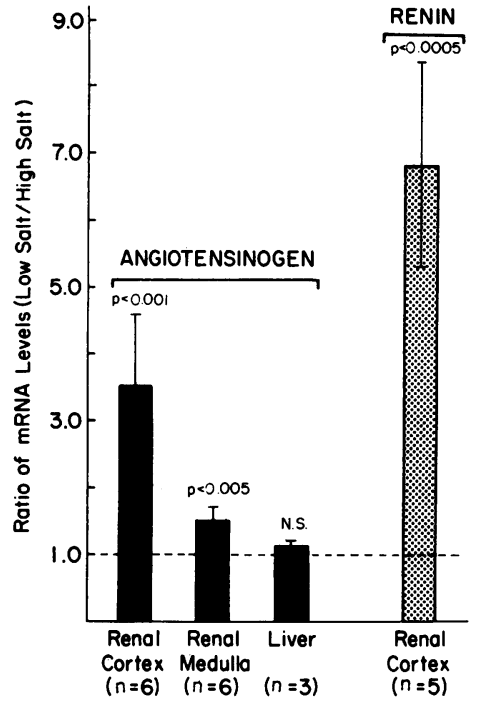

Figure 3. Ratios of slopes generated from densitometric analysis of hybridization signals representing angiotensinogen and renin mRNAs on high and low salt diets. For each blot, serial quantities of total RNA were employed, and densitometric areas were calculated. A regression line was then generated. For each tissue, the ratio slopes for low/high salt were computed. A ratio of 1.0 implies no change in mRNA level as a result of changing salt diet (dotted line).

of the renin-angiotensin system cannot distinguish between contamination or uptake from plasma vs. in situ synthesis. Using nucleic acid hybridization techniques, the present study provides evidence that angiotensinogen mRNA is synthesized within the kidney, and is localized in both the cortex and medulla. It would appear that sodium state affects cortical renin and cortical angiotensinogen mRNAs in parallel. Medullary angiotensinogen mRNA also appears to be influenced by sodium state; furthermore, there appears to be little medullary renin mRNA, which suggests that the kidney dissections were accurate.

Previous studies have suggested that angiotensinogen might be present in the kidney. For instance, microsomal fractions of the renal cortex have been reported to possess "angiotensinogen"containing granules (6). Immunocytological localization of angiotensinogen in the rat renal cortex was reported by Richoux et al. (3). When hepatic release of angiotensinogen was suppressed by colchicine no kidney staining was seen, leading Richoux et al. to conclude that the angiotensinogen seen in the kidney was hepatic in origin. Other investigators have been unable to identify angiotensinogen by immunocytochemical methods at all $(4,5)$. Recently, Ohkubo et al. reported the detection of angiotensinogen mRNAs in many tissues including whole rat kidney (20). Using a synthetic 30 -mer oligonucleotide primer to the 5 coding region of angiotensinogen mRNA (21), Fried and Simpson reported positive dot blot hybridization with poly A+ RNA of rat renal medulla but not cortex. Our data differ from that of Fried and Simpson. Using a cDNA probe, we can detect angiotensinogen mRNA in apparent similar amounts in both renal cortex and medulla. The difference in the length of the probes (530base cDNA probe as opposed to a 30-mer synthetic probe) and the method of hybridization (Northern vs. dot blot) may, in part, explain the disparity. The accuracy of our findings is supported by the use of stringent wash conditions, and the performance of Northern blots. Indeed, the sizes of our renin and angiotensinogen transcripts are similar to those reported in the literature.

The finding that the angiotensinogen mRNA level appears to be influenced by sodium state is novel. It would fit well with our concomitant observations concerning increases in renin mRNA with low salt diet. Recent reports by Nakamura et al. (22) and Darby et al. (23) have demonstrated renin mRNA in the rat and ovine kidney, respectively. In the Nakamura study, sodium depletion plus captopril increased renin mRNA levels in the kidney.

The renin-angiotensin system is intimately involved in the modulation of glomerular function. AII influences glomerular microcirculation, causing reductions in plasma flow rate and ultrafiltration coefficient and increase in hydraulic pressure difference and renal arteriolar resistance (24-26). It has been shown that glomerular mesangial cells contract in response to AII, which appears to lower the ultrafiltration coefficient (27). In addition to physiologic studies, various components of the renin-angiotensin system have been localized to the renal cortex by immunocytochemical techniques. For instance, Taugner et al. have shown renin in the afferent and efferent arterioles, interlobular arteries, and also in proximal, connecting, and cortical collecting tubules by staining with antirenin antiserum, using the peroxidase-antiperoxidase technique (4). They also demonstrated converting-enzyme immunoreactivity in proximal tubules as well as AI and AII in juxtaglomerular epithelial cells (4). Naruse et al. have provided immunohistochemical evidence that $\mathrm{AI}$ and AII are present in juxtaglomerular cells (28). AII receptors have been found abundantly in the glomeruli, and in lower concentrations in cortical tubular fractions $(2,29,30)$. Also, we have observed that cultured glomerular mesangial cells synthesize renin intracellularly (31). Because changes in glomerular microcirculation occur rapidly, the local availability of angiotensinogen whose expression is regulated by local events is an attractive possibility. This postulate is supported by the finding in the present study of regulatable mRNA specific for angiotensinogen in the renal cortex. The present study not only shows both angiotensinogen and renin mRNAs to be expressed in the renal cortex, but that they respond in similar fashion to sodium diet. In contrast, hepatic angiotensinogen mRNA expression does not appear to be influenced by dietary sodium intake. The exact mechanism by which dietary sodium affects renal angiotensinogen mRNA expression remains to be defined. Nevertheless, out data suggests that tissue-specific regulation of angiotensinogen expression exists in the rat. One may postulate that in low sodium states, differential regional increase in renal angiotensinogen might provide additional substrate for the local production of angiotensin that may then influence regional or local renal responses.

The finding of angiotensinogen mRNA in the renal medulla raises questions as to its function. Little renin is present in the medulla, but ample renin might reach the medulla from cortical regions via microcirculation or lymphatics (32). Recently, AII receptors have been described by Mendelsohn and others in the location of vasa recta bundles $(2,29,30)$. This location would permit the renin-angiotensin system to be involved in the control of regional medullary blood flow and the counter-current mechanism. Additionally, AII binding sites have been demonstrated in renal medullary (as well as cortical) tubule segments $(2,29$, 30). A possible physiologic function for the receptors has been demonstrated by Chou et al. (33), who infused AII unilaterally into the renal artery in a canine model at a dose that did not alter glomerular filtration rate or renal plasma flow. This manipulation resulted in ipsilateral sodium retention, an increase in urinary osmolality, and papillary ischemia. Indeed, papillary plasma flow has been demonstrated to be affected by events that increase or decrease plasma renin activity. For instance, the increase in circulating renin known to accompany diuretic administration has been demonstrated to be associated with de- 
creases in papillary blood flow. The expression of angiotensinogen in the medulla lends credibility to the possibility that the renin-angiotensin system is present locally, and is intimately involved with on-site regulation.

The finding of angiotensinogen mRNA in the kidney, both in cortex and in medulla, provide further support for the existence of an intrarenally regulated renin-angiotensin system. It will be important to localize the specific cell type(s) that synthesize(s) renin, angiotensinogen, and angiotensins, using in situ hybridization, to understand the relationship of the components of this intrarenal system. This knowledge will have important implications for understanding the manner in which the kidney adjusts its microenvironment. Further investigations on the regulation and function of this system, using molecular biological techniques, are now possible.

\section{Acknowledgments}

We thank Drs. Kenneth Gross and Kevin Lynch for providing the plasmids, pDD-1D2 and pRang 3, respectively. We also thank Dr. Joseph Majzoub for helpful discussions. We thank Ms. Sarah Curwood for excellent secretarial assistance.

This research was supported by NHLBI HL 19259, HL 35610, HL 35792, National Institutes of Health (NIH) Specialized Center of Research in Hypertension HL-33697, the Milton Fund, and R. J. Reynolds-Nabisco, Inc. Dr. Victor J. Dzau is an Established Investigator of the American Heart Association. Dr. Julie Ingelfinger is the recipient of an NIH Senior Fellowship Award HL-06913.

\section{References}

1. Inagami, T., T. Okamura, D. Clemens, M. R. Celio, K. Naruse, and M. Naruse. 1983. Local generation of angiotensin in the kidney and in tissue culture. Clin. Exp. Hypertens. Part A. Theory Pract. A 5(7\&8): 1137-1149.

2. Mendelsohn, F. A. O. 1982. Angiotensin II: evidence for its role as an extrarenal hormone. Kidney Int. 22(Suppl. 12):S78-S81.

3. Richouz, J. P., J. L. Cordonnier, J. Bouhnik, E. Clauser, P. Corvol, J. Menard, and G. Grignon. 1983. Immunocytochemical localization of angiotensinogen in rat liver and kidney. Cell Tissue Res. 122:439-451.

4. Taugner, R., E. Hackenthal, U. Helmchen, D. Ganten, P. Kugler, M. Marin-Grez, R. Nobiling, T. Unger, I. Lockwood, and R. Keilbach. 1982. The intrarenal renin angiotensin system. Klin Wochenschr. 60: 1218-1222.

5. Taugner, R., E. Hackenthal, E. Rix, R. Nobiling, and K. Poulsen. 1982. Immunochemistry of the renin-angiotensin system. Kidney Int. 22:(Suppl. 12):S33-S43.

6. Morris, B. J., and C. I. Johnston. 1976. Renin substrate granules from rat kidney cortex. Biochem. J. 154:625-637.

7. Goldstein, D. J., A. Diaz, S. Finkielman, V. W. Nahmoud, and C. Fischer-Ferraro. 1973. Regulation of the in vitro synthesis of angiotensin. Proc. Soc. Exp. Biol. Med. 142:793-795.

8. Page, I. H., and O. H. Helmer. 1940. Angiotonin-activator, renin, angiotonin inhibitor, and the mechanism of angiotonin tachyphylaxis in normal, hypertensive, and nephrectomized animals. J. Exp. Med. 71 : 495-519.

9. Dzau, V. J., J. R. Ingelfinger, R. E. Pratt, and K. E. Ellison. 1986. Identification of renin and angiotensinogen mRNA sequences in mouse and rat brains. Hypertension. 8:544-548.

10. Lynch, K. R., V. I. Simnad, E. T. Ben-Ari, and J. C. Garrison. 1986. Localization of preangiotensinogen mRNA sequences in the rat brain. Hypertension. 8:540-543.

11. Kageyama, R., H. Ohkubo, and S. Nakanishi. 1985. Induction of rat liver angiotensinogen mRNA following acute inflammation. Biochem. Biophys. Res. Comm. 129:826-832.

12. Campbell, D. J., J. Bouhnik, J. Menard, and P. Corvol. 1984.
Identity of angiotensinogen precursors of rat brain and liver. Nature (Lond.). 308:296-308.

13. Herrmann, H. C., and V. J. Dzau. 1983. The feedback regulation of angiotensinogen production by components of the renin-angiotensin system. Circ. Res. 52:328-334.

14. Ulrich, A., J. Shine, J. Chirgwin, R. Pictet, E. Tischer, W. J. Rutter, and H. M. Goodman. 1977. Rat insulin genes: construction of plasmids containing the coding sequence. Science (Wash. DC). 176:13131319.

15. Glisin, V., R. Crkvejakov, and C. Byus. 1974. Ribonucleic acid isolated by cesium chloride centrifugation. Biochemistry. 13:2533-2537.

16. McMaster, G. K., and G. G. Carmichael. 1977. Analysis of singleand double-stranded nuclei acids on polyacrylamide and agarose gels using glyoxal and acridine orange. Proc. Natl. Acad. Sci. USA. 74:48354838.

17. Thomas, P. D. 1980. Hybridization of denatured RNA and small DNA fragments transferred to nitrocellulose. Proc. Natl. Acad. Sci. USA. 77:5201-5205.

18. Field, L. J., R. A. McGowan, D. P. Dickinson, and K. W. Gross. 1984. Tissue and gene specificity of mouse renin expression. Hypertension. 6:597-603.

19. Ohkubo, H., R. Kageyama, M. Uhihara, T. Hirose, S. Inayama, and S. Nakanishi. 1983. Cloning and sequence analysis of cDNA for rat angiotensinogen. Proc. Natl. Acad. Sci. USA. 80:2196-2200.

20. Ohkubo, H., K. Nakayama, T. Tanaka, and S. Nakanishi. 1986. Tissue distribution of rat angiotensinogen mRNA and structural analysis of its heterogeneity. J. Biol. Chem. 251:319-323.

21. Fried, T. A., and E. A. Simpson. 1986. Intrarenal localization of angiotensinogen mRNA by RNA-DNA dot blot hybridization. Am. J. Physiol. 250:F347-F377.

22. Nakamura, N., F. Soubrier, J. Menard, J.-J. Panthier, F. Rougeon, and P. Corvol. 1985. Nonproportional changes in plasma renin concentration, renal renin content, and rat renin messenger RNA. Hypertension. 7:855-859.

23. Darby, I. A., P. Aldred, R. J. Crawford, R. T. Fernley, H. D. Niall, J. D. Penschow, G. B. Ryan, and J. P. Coghlan. 1985. Renin gene expression in vessels of the ovine renal cortex. Hypertension. 3:9-11.

24. Ichikawa, I., J. F. Miele, and B. M. Brenner. 1979. Reversal of renal cortical actions of angiotensin II by verapamil and manganese. Kidney Int. 16:137-147.

25. Blantz, R. C., K. S. Konnen, and B. J. Tucker. 1976. Angiotensin II effects upon the glomerular microcirculation and ultrafiltration coefficient of the rat. J. Clin. Invest. 57:419-434.

26. Myers, B. D., W. M. Deen, and B. M. Brenner. 1975. Effects of or norepinephrine and angiotensin II on the determinants of glomerular ultrafiltration and proximal tubule fluid reabsorption in the rat. Circ. Res. 37:101-110.

27. Schor, N., I. Ichikawa, and B. M. Brenner. 1981. Mechanisms of action of various hormones and vasoactive substances on glomerular ultrafiltration in the rat. Kidney Int. 20:442-451.

28. Naruse, K., I. Inagami, M. R. Celio, R. J. Workman, and Y. Takii. 1982. Immunohistochemical evidence that angiotensins I and II are formed by intracellular mechanisms in juxtaglomerular cells. $H y$ pertension. 4(Suppl. II):70-74.

29. Mendelsohn, F. A. O. 1985. Localization and properties of angiotensin receptors. J. Hypertension. 3:307-316.

30. Mujais, S. K., S. Kauffman, and A. I. Katz. 1986. Angiotensin II binding sites in individual segments of the rat nephron. Kidney Int. 29:254. (Abstr.)

31. Dzau, V. J., and J. I. Kreisberg. 1983. Cultured glomerular mesangial cells contain renin: Influence of calcium and isoproterenol. Kidney Int. 25:328. (Abstr.)

32. Dzau, V. J., C. S. Wilcox, K. Sands, and P. Dunckel. 1986. Dog inactive renin: biochemical characterization and secretion into renal plasma and lymph. Am. J. Physiol. 250:E55:E61.

33. Chou, S. Y., P. F. Faubert, and J. G. Porush. 1986. Contribution of angiotensin to the control of medullary hemodynamics. Fed. Proc. 45:1438-1443. 